\title{
Review of Canadian Curriculum Studies: A Métissage of Inspiration/Imagination/Interconnection
}

\author{
Barbara McNeil \\ University of Regina
}

Perusing, skimming and scanning are part of reviewing books and soon after moving through Hasebe-Ludt's and Leggo's (2018) edited volume, Canadian Curriculum Studies: A Métissage of Inspiration/Imagination/Interconnection, I knew that this one would be extraordinary. What made it so is that this expansive work on Canadian curriculum is generously speckled with beads of lights from art, poetry, photographs ("analogue" and digital) and language, richly evocative and provocative. Marked by what is referred to as the "Leggo phenomenon," this monograph is a beating heart of contemporary curriculum scholarship; it provokes appreciation, excitement, satisfaction, curiosity, open-mindedness, and love of poetry so reminiscent of the late Carl Leggo, our friend and muse. He though, would be among the first to express homage to, and gratitude for the impressive offerings of the collaborators and friends whose work share a home in the métissage. This timely, insistent and memorable collection, presents a plurality of voices - each offering, mindful, unique and relevant perspectives emerging from, and related to the curriculum field in Canada.

In their overture - their "ruminations," the editors of this gift to Canadian curriculum scholarship explain the meaning of métissage - a word emerging from the Latin mixticius, meaning a cloth from different fibres" (p. xxi)... This carefully articulated definition, pinpoints that, in "curricular and pedagogical contexts, métissage encourages genuine exchange, sustained engagement, and the tracing of mixed and multiple identities... xxii). For Hasebe-Ludt and Leggo, the multivocality of the book's contributors "works against notions of purity by seeking affinities and resonances" (p. xxii) between and among the scholars whose work are gathered in this polyphonous text dedicated to Canadian curriculum scholar Ted Tetsuo Aoki. With this, is signaled a work and world that proves to be lovingly conscious of its celebrated genealogy e.g., - the past, (Aoki and Huebner), present (Pinar) and progeny (the contributors, readers and users of this salutary addition).

Whether delivered through text and images, and in some cases, a mixture of both, the collection's multiplicity of voices are gathered in three parts|: Métissage A: Inspiration: Topos/Language/Sound, Métissage B: Imagination: Identity/Ethos/Spirit, and Métissage C: Interconnection: Relations/Healing/Pathos. The three gift-giving parts are well-served paratextually by a table of contents, a poem about the cover art, list of contributors, and an index.

The portal to Métissage A is an acrylic painting — "Landscape Invocations” by Rita Irwin and is indicative of the rich arts-based, multi-modality (visual art, prose poetry, and multi-generic expository texts) of the book. Hers, is one of the five thoughtful invocations in this section of the book. It is a fitting tribute to the topos (Greek word roughly translated as place) - a mirror image of the land and/or land and sky. Perhaps, this is a visually inspired, spiritual way to honour the site/land of the Provoking Curriculum gathering (2015) that motivated these stellar pieces of visual and written texts and the métissage of people responsible for them.

"Landscape Invocations" invokes the spirit of the land and sky-the sources of creation and sustainability. A1 respectfully, and rightly begins with writing by Sheena Koops, an 
Indigenous woman (Métis), and educator who writes about “...Walking, Writing, and Singing Treaty Education." In this clear-eyed and moving piece, Koops reminds us that we are all Treaty people, and that "... ally work is not begun by perfect or perfectly prepared people (p. 8). Amen to that! This piece resonates powerfully with me, and is likely to do so with scores of Canadian readers now taking their/our first teetering steps towards being an ally and understanding the meaning of the Treaties and the responsibilities associated with the privilege of living on this land, now called Canada but remains Turtle Island.

Of the nine expository items in Métissage A, the one by Wisam Kh. Abdul-Jabbar is likely to reverberate intensely with teacher-educators and their students. The writing speaks compellingly to the past, present, and future impact of hegemonic linguistic ideologies in Canada. This excellent paper employs Kristeva's concept of the chora to look at the "insidious effects of learning a new language upon one's mother tongue and ethnic identity within the context of immigration" (p. 47). Required reading for all, Abdul-Jabbar argues that the "process of acquiring a new language can trigger a process of ethnic erosion in terms of one's first language and identity." (p. 47) and calls for more nuanced, decolonial, and compassionate pedagogical approaches to second language acquisition.

But even at this early stage in the paper, a corrective/elaboration is needed. Ethnic/cultural erosion is not a new phenomenon in Canada; it dates back to the triumph of the colonizers over Indigenous peoples of North America (sic Canada) and the severing of the linguistic - maternal chora for Indigenous peoples in Canada through residential schools. This does not mean the experience is any less significant for immigrant children and peoples, only that what is happening today is the reification, recuperation, in fact, continuation of Canada's deeply rooted colonial policy of linguistic hegemony and emaciation, if not death of the mother tongue for children of non-dominant groups in schools. Who among us can deny that "[most] schools enunciate a new chora, a maternal surrogate that generates a process of "spacing," which can cause ethnic values to erode" (p. 47). Nonetheless, Adul-Jabbar remains optimistic. He argues that "since the creation of a new chora that functions against the authentic one seems inevitable; curriculum writers need to think of more ways to salvage the ethnic chora so it does not dissipate (p. 52). Adul-Jabbar is hopeful and believes in their agency. He concludes with suggestions that "future directions in Canadian curriculum should hopefully strive to generate a 'spacing' that negates and resists firstlanguage attrition" (p. 53). I concur.

Though desirable, it is impossible to explore all entries in Métissage A. Nonetheless, the three pieces discussed above are representative of the three predominant voices in Canada: The Indigenous, the first settlers/immigrants, and the more recent and future ones.

As concerns the second grouping of papers: Métissage B, like A, pulsates with the energies, tellings, and visual text of multiple creators, but here, gathered together under the theme of Imagination: Identity/Ethos/Spirt. This braiding of texts begins with Thomas's "Provoking the Intimate Dialogue: A Path of Love" - an invitation, a plea for a curriculum that "draw[s] intimacy into the classroom," intimacy connected "to the knowing of things" (p. 88) and people up close, deeply and closely. Using the conditional, she asks, "What if ...we approached learning through the Sufi path, enabling educators and learners to take on the roles of lover and the Beloved, enabling an Intimate Dialogue?" In asking the question, Thomas gestures toward new possibilities, new pathways for constructing curriculum for, and with, self and other and the place to begin is the "Imaginal Realm." Thomas's incantation to innovative approaches to interrelationality in 
classrooms and beyond is followed by Grimmett's condensed cautionary contribution in which he argues that "sometimes, we may become so caught up with all sorts of legitimate pursuits that we do not realize that the roots of such pre-occupations are diverting the focus away from the academic curriculum" (p. 97). Proceed with caution is the incantation here.

Not unlike Métissage A, the editors are nimble in their contrapuntal arrangement of the multigeneric pieces in Métissage B. Featured here also are offerings that rub-up against, contest, and sometimes complement each other. Readers, the beneficiaries, are amply rewarded for their journey by being immersed in a diversity of ideas, ruminations, and invocations about the antecedents of current thinking about curriculum (e. g., White's "Eros, Aesthetics, and Education..." and Liu Baergen's "Theorizing as Poetic Dwelling: An Intellectual Link between Ted Aoki and Martin Heidegger"). As well, we find rigorous discussions about the futurities of curriculum (e.g., Seidel's Invocation on "Curriculum Grammar for the Anthropocene", Oladi's "Rumi and Rhizomes: The Making of a Transformative Imaginal Curriculum, and Nazari's and Heng Harste’s “Religion, Curriculum, and Ideology: A Duoethnographic Dialogue”).

Not to be missed in Métissage B is den Heyer's "Lane Musings," a consequential threequarter page Invocation that draws on observations of Magpies hopping, to assert that "it is difficult to hop with grace like a magpie on one leg" (p. 151).

To be graceful on one leg while pretending to have two is what many Canadians have been trying to do with half a history about who we were, are, and hope to be..." In his Invocation, den Heyer asks, "Here, now, we are, but how do we do so gracefully if we can only try to hop forward on one leg?" (p. 151). A timely provocation; the question posed indicts Canadian curriculum and challenges curriculum scholars, teachers and students to act ethically and responsibly to ensure that colonialism and its ongoing legacies are no longer occluded from our ongoing historical script and that its impacts are justly addressed. Acknowledging the land on which he lives (Treaty 6), the author, prompts us to enact our treaty obligations.

Moving on now to the last set of texts and Invocations, we find Métissage C. It sings sweetly of Carl Leggo and now that he is gone, it pulls tenderly at the hearts of those who knew him and/or of his work. Here, as the editors state, we encounter works that "highlight the creative, poetic, narrative, ruminative, performative interactive, and imaginative nature of the [curriculum] field" (p. xxxiii). Entitled, Interconnection: Relations/Healing/Pathos, this section of the book, as the others, weaves a beautiful tapestry that showcases contributions and voices from new, emerging, and experienced, as well as scholars who have achieved elder-like status, in the curriculum field.

Métissage $\mathrm{C}$ begins with exemplars of interconnectivity between two sets of researchers (C1: Clarke \& Hutchinson) and (C2: Bartlett \& Quinn)) telescoping not only collaboration between scholars but also their frankness, collegial intimacy, vulnerability, playfulness, curiosities, and tensions. The latter pair for instance explain that "dwelling within the tension between curriculumas lived and curriculum-as-plan, or attunement, becomes a knowing and understanding of one's self and the others in the community as well as an active and conscious weaving of living disciplines throughout" (Bartlett \& Quinn, p. 205).

Another, noteworthy, appreciable journey taken up in C3-is, "Dwelling in Poiesis." It is a reflective piece offering much wisdom about the potentialities of a school garden, which enriches the tapestry of the section by "juxtapos[ing] ... image and language [to reflect] the ambiguity of 
representing ...learning in a way that addresses Merleau-Ponty's idea of a structural correspondence between lived experience and the expressive power of words" (p. 207). Turner's poetry brings forward her garden practice in a striking manner. For instance, she explains that "work in a schoolyard garden allows us to interact with the living world in a purposeful role that assigns us both accountability and agency, incorporating us into the body of the garden community" (p. 208). Furthermore, her pastel images are as lush as her prose poetry and emphasize circularity and connectivities through the use of soft, rounded lines. Truly impressive!

Turner's piece is suitably followed by Jardine's touching Invocation, “To Know the World, We have to Love." Its inclusion and positionality in Métissage C is indicative of careful, intentional editorial work that ultimately engages readers emotionally and spiritually. Thank you Erika and Carl! With an ending that emphatically states, "No. Love is not an outcome of the right circumstances but a cause of right circumstances" (p. 225), we are well-prepared to tackle the next entry-C 4-that deals with "Difficult Knowledge."

In this autobiographical, confessional piece, Harrison details an occasion where she "backed away from opportunities to engage" her students in difficult knowledge_- “...painful conversations" about gender and sexual violence (p. 228). Harrison gives voice to curricular drivers, challenges, and suppressions that many, if not all, teachers have encountered and enacted. By drawing on the works of scholars such as Grumet (1988), Arendt (1993) and Pitt and Britzman (2003), Harrison shares why and how she wrestled with the suppression of difficult knowledge (e.g., about rape culture, patriarchy and feminism). She leads us to see that, ethically and relationally speaking, we do not have the luxury of failing, of not "taking responsibility for the world as it is" (p. 230). In reflecting on, and interrogating - provoking-her curricular decisions, Harrison notes that "taking seriously that responsibility (of engaging with difficult knowledge) will not only make [her] a more effective - and affective - teacher, but may also offer students a model for their developing pedagogies" (p. 231-232). Harrison's pedagogical memoir is an entry that typifies the quality of writing and the powerful arts-based content found in the Métissage A, $\mathrm{B}$, and $\mathrm{C}$.

Rich in entries that convincingly illuminate themes of relationality, healing, and pathos, C4 is only one of the substantive examples to which readers will be drawn. In "Kizuna: Life as Art," Gillard explores the liminality and lived sadness of being born on one side of the Pacific Ocean (Japan) and living on the other (Vancouver) when her country of origin suffered a massive earthquake. Gillard's granular, visual art (digital photographs) and poetry compellingly captures and materializes the difficult but necessary journey home to witness, grieve, and assist those who lived through it-showing that life and art are "integrally connected" (p. 245). Kizuna's piece is yet another testimony of arts-based sensibilities the editors brought to bear on this métissage.

The idea of journeying to bear witness, and to participate in construction and reconstruction is picked up in C7: "Dadaab Refugee Camp and the Story of School" (Meyer et al.). Here, readers are provided "[w]indows to a [p]lace" (p. 257) - (the third largest refugee camp in the world, located in south eastern Kenya, near the Somali border) and the "[c]all to [e]ducation" (p. 259)an enduring hope of our world. Similar to many in the volume, this paper is autobiographical for one of the authors - "a personal narrative." Additionally, it educates about what is possible over 25+ years through the indefatigable determination of refugees - children (knowledge and activation of their own learning styles), parents, teachers, curriculum workers, NGOs, volunteers etc.). This paper reminds us that "establishing and maintaining schools in refugee camps is fraught 
with ongoing challenges, particularly funding constraints," (p. 263) but is necessary. As well, the entry invites our collaboration/cooperation, advocacy and hope to continue the "success that has been created" (p. 263) in the Dadaab camps.

\section{Conclusion}

Books about curriculum often cater primarily to the cognitive. Not so this one. With its dazzling, crimson-hued cover page art, Canadian Curriculum Studies: A Métissage of inspiration/imagination/interconnection is a fresh, lush, contemporary compilation of diverse expressive threads, woven/braided into a fabric of richness that is cerebral, affective, spiritual, visual and overall, quite magical. Wherever found in the collection, the poetry rocks and rocks! Thank you Erika and Carl!

This monograph offers up a cornucopia, a panorama of ideas, events, stories, histories, testimonies, dialogues, reflections, remembrances, confessions, invocations and provocations about, and around, a range of topics, and content of varying lengths, important to diverse Canadian curriculum scholars/watchers/dabblers/participants/critics. Thus, almost two decades into the $21^{\text {st }}$ century, this is an indexical work about curriculum studies/conundrums/interests/interest and desires that looks back, around, up, down and ahead. It is of wide appeal and is likely to be (be)friended now as well as later. Such an achievement owes much to the deftness, inclusivitydriven, sage, sensitive, nuance-conscious, and yes, curious and passionate editors whose openness and magnanimity are beautifully diffused in this assemblage and bricolage.

In other words, the book succeeds as evidence of the métissage of the country and its peoples - their intersections and interrelationalities. There is considerable richness here. Every piece is moving and intriguing and although much difficult knowledge is confronted and teased out, the clarity, honesty and emotional depth of this multigeneric/blended work is irresistible and difficult to miss throughout the 301 plus pages. This is captured in the piece by Kurki, Herriot, and French Smith (C10) who invite readers to "deliberately choose joyful experiences of learning, teaching and research" thereby rebuking the not-so-hidden gendered curriculum of "busy," and its pervasive effects" (p. 298). These scholars wisely suggest we centre "the joy of learning, which is in fact the joy of vulnerability." Gripping. Compelling. Right on!

In sum, this provocative, tender, and excellently "braided" work - this métissageexplores, mines, provokes, pushes, questions, stirs, and challenges. It is full of hope in its wide ethical orientation. A way to honour this precious gift about current strands and storylines in Canadian curriculum studies is to commit to memory, the last lines in its final invocation. In C10, Walsh writes, "May we turn toward one another and the world: strengthen our intention to love well together" (p. 301). There is no higher purpose for Canadian curriculum studies. And if reviewers are allowed any indulgences, mine would be this: regret and apology that I could not discuss every single entry in this superlative and unforgettable volume. Mea, culpa. Thank you Erika! And thank you Carl, our collaborator, mentor, muse, and friend; this is not goodbye, only so long.

Hasebe-Ludt, E., \& Leggo, C. (Eds.). (2018). Canadian curriculum studies: A métissage of inspiration/imagination/interconnection. Toronto, ON: CSP Books. 